\title{
Implementation of Community Policing Strategy: Impact of Community Factors in Nairobi Country
}

\author{
Robert Gichangi Kabage \\ P.O Box 2704,Nakuru
}

\begin{abstract}
Crime is a community problem and not just a police problem. The adoption and implementation of Community Policing (CP) in the 1980s, was perceived as departure from the professional "police-asexpert' model of public safety that had been dominant for a long time. The CP approach is designed to engage the community as an equal partner in solving local crime and other security threats within the community. The CP concept was introduced in Kenya in the 1990s. Though it had informally existed in Nairobi County in Ruai and Kasarani estates much earlier.Its formal implementation only gained currency after the Post Election Violence of 2007-2008 in Kenya. Among the factors influencing its implementation in Kenya has received considerable research attention, but challenges impacting on its implementation in Nairobi County have not been adequately documented. This study aimed to fill this research gap by focussing on community factors. The overall research objective sought to determine the influence of community factors in effective implementation of community policing within Nairobi County. The objective of the study was to assess how community factors influence implementation of community policing within Nairobi County. The research findings adds to the body of knowledge, while also benefitting policy makers dealing with issues of community policing. It will also benefit other researchers exploring different aspects of community policing as a strategy to combat crime in city neighbourhoods. The research established that community factors are among the most influential factors that hamper smooth implementation of community policing in Nairobi County. The study recommends that the community needs to be educated on community policing initiatives and how to manage community factors that affect the implementation of CP in Nairobi County.
\end{abstract}

\section{Keywords; Community Policing, Community factors, Crime Prevention, Partnerships}

\section{Introduction}

In the last three decades, research has attributed inadequacy of crime fighting in Africa to the methods of policing that were being used (Moore, 2012). This led to the study and eventual introduction of a new policing model known as Community Policing (CP) between 1970s and 1990s, as a new strategy to fighting crime more comprehensively. The model was heralded as a positive paradigm shift to fighting crime since it was anchored on the concept of engaging the community as an equal partner in solving local crimes (Seagarve, 2012).

Community policing or neighbourhood-oriented policing can be defined as an approach to policing that recognizes the independence and shared responsibility of the police and the community in ensuring safe and secure environment for all citizens. It aims at establishing an active and equal partnership between the police and the public through which crime and community safety threats can jointly be discussed, solutions found and implemented. It is premised on the belief that people deserve and have a right to say how their communities are policed in exchange of their involvement and support (Lilley, 2006).

The concept of community policing was first implemented in the United States of America and the United Kingdom from the 1980s.It was based on the principle of coordination and consultation between the police and the policed. However, in developing countries, CP has been presented as a viable strategy to re-build trust between the police and the public and to improve security (Toch, 2002). This is attributed to the 
adversarial characteristics of the relationship between the police and the public in those countries. It is mostly being implemented in countries that are emerging from different kinds of conflicts or making a transition from years of authoritarian rule characterized by politicization of policing institutions, gross abuse of human rights by the police and lack of accountability (Giacomazzi et al,2014).

In Kenya, the concept of community policing was introduced in the 1990s. It was however not seen as a very new concept because most communities in the country have always practiced the principle of being each other's keeper through traditional customary practices. Most rural communities practiced the concept of community policing due to a shared cultural identity.

It is however, the 2007-2008 post-election violence (PEV) in Kenya that accelerated calls for the National Police Service to deliberately undertake reforms in the organization. The National Task Force established to investigate the PEV, recommended that policing agencies should embrace community policing as one of the strategies of crime prevention. It recommended fast tracking of a National Community Policing Policy (NCPP), to provide a legal and institutional framework for the implementation of CP (GoK, 2009). The new constitution of Kenya,that was promulgated in August 2010,also empowered citizens to play a role in the management of their security. The National Police Service Act of 2011 further provided for community policing by establishing Community Policing Committees (CPC) as one of the mechanisms of operationalizing community policing In Kenya.

In Nairobi County, successful community policing initiatives have existed in places like Ruai and Kasarani sub-counties for some time now, and community-policing programmes have been praised by the community for contributing to reduced crime rates, while providing a forum for the community to discuss local security issues with police officers (Ruteere \& Pommerolle, 2013). This success has not been without challenges, especially those from community factors.

\section{Theoretical Framework}

The General Systems Theory (GST) anchors this study. The theory was originally proposed by biologist Ludwig von Bertalanffy in 1928. The theory focuses on the system's structure instead of the system's function. Its premise is that, complex systems share organizing principles and therefore parts of a system are best understood in the context of the whole (Brand, \& Birzer, 2003). GST when applied to social organizations such as police departments, it stresses on the openness of the organization and the interaction with the environment in inputs and outputs (Brand \& Birzer, 2003). One of the main ideas of GST is that all systems must maintain equality between inputs and outputs since systems are developed from sets of components that work together for the overall objective of the whole (Forman , 2004). In this regard, community factors are part of the inputs to the community policing process. The outputs include controlled crime levels in the community. Notably, the functions of these factors are out of the police responsibility area. That explains the reason why crime prevention activities must be performed in cooperation with all other key players that are responsible for carrying out their relevant complementary tasks. This then underscores the need for the community to be involved in the work of policing.

\section{Methodology}

This study adopted a descriptive research design, using both quantitative and qualitative methods. A research design is a plan or a blue print that guides and informs how a study will be conducted (Bittner, 2010). This implies that procedures by which we approach problems will determine the solutions. The research design entailed choosing subjects to participate in the study, techniques and approaches for collecting data from the subjects and the procedure for collecting the information on aspects in the implementation of community policing. The mixed approach research design of collecting both qualitative and quantitative data was the most suitable in this study because, it involved measurements of the variables in the implementation of strategies for community policing. The study was also guided by the target population, which is defined by Kothari (2014), as the entire group of individuals, events or objects having common observable characteristics. In this study, the target population comprised subordinate officers in Kenya Police Service of the ranks of Constable, Corporal, Sergeant and Senior Sergeants within Nairobi County. According to the Kenya Police records (2013), there are 2,883 police officers stationed in various 
police divisions in Nairobi. The Kenya Population and Housing Census (2010), puts the household population for Nairobi County at 985,016 households.

Given that the study population was too big, a smaller subset of the entire research population was selected to represent the study population. This is known as the sample (Bittner, 2010). A Multi stage sampling technique was applied to draw the sample from the population. First, each police division served as a stratum. From each division (stratum), simple random sampling technique was used. This was preferred because it ensured that each and every unit in the population had an equal and independent chance of being included in the sample. The sample size was then determined using a formula suggested by Mugenda \& Mugenda (2010) as shown below:

$\boldsymbol{N}$ is the population size; and $\boldsymbol{n}$ is the desired sample size with the population of over 10,000 . A $95 \%$

confidence level is assumed for the equation.

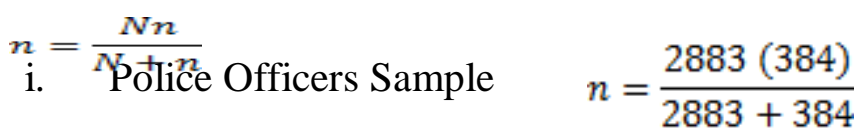

$$
\begin{aligned}
& =339 \text { police officers }
\end{aligned}
$$

\section{Findings}

The major community factors influencing the implementation of community policing in Nairobi County included: Cultural pluralism, Multi-ethnicity, Level of community commitment, Interest and willingness by residents, Community knowledge on the benefits of $\mathrm{CP}$, Moral level of the community and the appreciation of police officers in dealing with crime. Questions were asked under each of these categories. Based on the General Systems Theory that was employed in the study, the findings were as follows:

\section{a. Cultural pluralism}

Cultural pluralism means a community with people from different cultural backgrounds. Gastrow (2011) opines that, there is great challenge when implementing $\mathrm{CP}$ in a community where there are people with different cultural backgrounds and so it needs to be handled carefully. The data analysis in Nairobi county revealed varying opinions with a majority of the respondents at $46.5 \%$ stating that cultural pluralism was an influential factor that affects the implementation of CP. Those who stated that cultural pluralism was not influential at all were in the minority of $9 \%$ as shown in the table below:

Table 1: Cultural pluralism

\begin{tabular}{|l|c|c|c|}
\hline Factor & Frequency & Percent $\%$ & Valid Percent\% \\
\hline Not influential & 28 & 9.00 & 9.00 \\
\hline Lowly Influential & 50 & 15.5 & 15.5 \\
\hline Neutral & 38 & 11.0 & 11.0 \\
\hline Influential & 152 & 46.5 & 46.5 \\
\hline Highly Influential & 60 & 18.0 & 18.0 \\
\hline Total & 328 & 100.0 & 100.0 \\
\hline
\end{tabular}

\section{Source: Field data 2019}

Additionally, most community members stated that differences of their cultural backgrounds divided them instead of bringing them together and this affected the partnership among themselves and with the police. Consequently, these differences were reflected in the implementation of $\mathrm{CP}$ within the community. This finding is supported by the General Systems Theory (GST), which states that the output of an organization depends on the input. In this case, one of the inputs is the cooperation of the community members towards the implementation of $\mathrm{CP}$, which is adversely affected by lack of cooperation of the community members arising from the diverse cultural backgrounds of the community. This has a negative impact on the implementation of CP.

\section{b. Multi-ethnicity}


Multi ethnicity denotes different tribes living together. The study found out that a majority of $40.56 \%$, of the respondents thought that this factor is influential. A minority of $7.9 \%$ stated that the factor was not influential. The table below represents the data according to the responses from the respondents.

Table 2: Multi- ethnicity

\begin{tabular}{|l|c|c|c|}
\hline Factor & Frequency & Percent $\%$ & Valid Percent $\%$ \\
\hline Not Influential & 26 & 7.9 & 7.9 \\
\hline Lowly Influential & 40 & 12.2 & 12.2 \\
\hline Neutral & 50 & 16.2 & 16.2 \\
\hline Influential & 136 & 40.56 & 40.56 \\
\hline Very Influential & 76 & 22.14 & 22.14 \\
\hline Total & 328 & 100.0 & 100.0 \\
\hline
\end{tabular}

\section{Source: Field data 2019}

Lee (2010) ,supports this finding in his study where he states that diversity in culture and tribe among the people makes it difficult for them to cooperate in order to achieve a single agenda. Similar to the different cultures among the various ethnic groups in a community, the same is also true among police officers. Multi ethnicity is thus a community factor that forms a component of the inputs in the police organization (according to the General Systems Theory (GST), which influences the implementation of CP in Nairobi County.

\section{c. Level of community commitment}

The level of community commitment towards the implementation of CP was also interrogated as part of the main objectives of the study. The study found out that the majority of the participants were in agreement that this factor was influential. $44.2 \%$ of the respondents stated that the factor was highly influential and only $6.6 \%$ stated that it was not influential. The table below represents the data according to the responses from the respondents.

Table 3. Level of community commitment

\begin{tabular}{|l|c|c|c|}
\hline Factor & Frequency & Percent $\%$ & Valid Percent\% \\
\hline Not Influential & 25 & 6.6 & 6.6 \\
\hline lowly Influential & 38 & 11.6 & 11.6 \\
\hline Neutral & 70 & 21.3 & 21.3 \\
\hline Influential & 50 & 15.2 & 15.2 \\
\hline Very Influential & 145 & 44.2 & 44.2 \\
\hline Total & 328 & 100.0 & 100.0 \\
\hline
\end{tabular}

\section{Source: Field Data 2019}

This finding is supported by Somerville (2010), who states that cooperation between the police and the community greatly determines the effectiveness of the CP implementation. This is because where a certain community is committed to partnering with the police, it is much easier to eliminate cases of lawlessness within the community and the level of $\mathrm{CP}$ implementation will be boosted. This factor is further supported by the General systems theory because lack of cooperation between the police and the community members affects the output, which is the implementation of CP.

\section{d. Interest and willingness of the residents}

The interest and willingness by residents of a given community to participate in community policing was also researched on. The study sought to find out if there was any impact on CP implementation by the interest and willingness of the community. The findings indicated that the majority of the respondents at $34.5 \%$, felt that it is not influential while $10.64 \%$ of them stated that it was influential. The data is represented in the table below. 
Table 4 : Interest and willingness by residents

\begin{tabular}{|l|c|c|c|}
\hline Response & Frequency & Percent $\%$ & Valid Percent $\%$ \\
\hline Not Influential & 120 & 34.5 & 34.5 \\
\hline Lowly Influential & 70 & 21.3 & 21.3 \\
\hline Neutral & 70 & 21.3 & 21.3 \\
\hline Influential & 28 & 10.64 & 10.64 \\
\hline Very Influential & 40 & 12.2 & 12.2 \\
\hline Total & 328 & 100.0 & 100.0 \\
\hline
\end{tabular}

\section{Source: Field Data 2019}

This finding is supported by a study undertaken by Reichel, (2002) which state that when a law is implemented in a society and some people begin to follow it, others will as well follow it without questioning.

\section{e. Community members' knowledge on benefits of CP}

The study was keen to find out whether community members' knowledge on the benefits of CP affects its implementation. As per the data below, majority of the respondents stated that it was influential at $40.4 \%$, while only $7.2 \%$ stated that it was not influential.

Table 5: Community knowledge on the benefits of COP

\begin{tabular}{|l|c|c|c|}
\hline Response & Frequency & Percent\% & Valid Percent\% \\
\hline not Influential & 23 & 7.2 & 7.2 \\
\hline lowly Influential & 30 & 11.1 & 11.1 \\
\hline Neutral & 55 & 16.8 & 16.8 \\
\hline Influential & 140 & 40.4 & 40.4 \\
\hline very Influential & 80 & 24.4 & 24.4 \\
\hline Total & 328 & 100.0 & 100.0 \\
\hline
\end{tabular}

\section{Source: Field Data 2019}

This finding is supported by a study conducted by Katz, \& Kahn (2011), where they state that awareness is a crucial factor that affects the implementation of CP, because, when members of the community are aware of the benefits of community oriented policing, they will embrace it and thus simplify the implementation process.

\section{f. Moral level of the community}

The study looked at whether the level of morality in the community has influence on the implementation of $\mathrm{CP}$. The findings showed that a majority of the respondents at $33.55 \%$ were neutral while a minority of $7.05 \%$ felt that the factor was not influential at all.

Table 6: The moral level of the community residents

\begin{tabular}{|l|c|c|c|}
\hline Response & Frequency & Percent & Valid Percent \\
\hline Not influential & 23 & 7.05 & 7.05 \\
\hline Lowly influential & 55 & 16.8 & 16.8 \\
\hline Neutral & 110 & 33.55 & 33.55 \\
\hline Influential & 90 & 27.4 & 27.4 \\
\hline very Influential & 50 & 15.2 & 15.2 \\
\hline Total & 328 & 100.0 & 100.0 \\
\hline
\end{tabular}

\section{Source: Field Data 2019}

This outcome is supported by Lee (2010), who opines that the major reason of implementing CP in society is to help in dealing with immorality and lawlessness levels within the community. However, regardless of whether the community is moral or not, the implementation of $\mathrm{CP}$ should be carried out.

\section{g. Appreciation of police efforts in fighting crime.}


The study sought to find out how appreciation of the police efforts by the community in fighting crime affects its implementation. The majority at $28.5 \%$ indicated that the factor was neutral, while $11.0 \%$ stated that the factor was not influential. The police effort was therefore of little influence on the implementation of the community policing as shown in the table below.

Table 7: Appreciation of the police efforts

\begin{tabular}{|l|c|c|c|}
\hline Response & Frequency & Percent & Valid Percent \\
\hline Not influential & 36 & 11.0 & 11.0 \\
\hline Lowly influential & 45 & 13.7 & 13.7 \\
\hline Neutral & 97 & 28.5 & 28.5 \\
\hline Influential & 60 & 19.4 & 19.4 \\
\hline Very influential & 90 & 27.4 & 27.4 \\
\hline Total & 328 & 100.0 & 100.0 \\
\hline
\end{tabular}

\section{Source: Field Data 2019}

This finding is supported by Manyange, (2014) who posits that appreciation by the community members is of little effect to the work of the police officers and equally is of minimal impact on the implementation of $\mathrm{CP}$. Majority of police officers were uncertain as to whether the factor of their appreciation by the community members affected the implementation of CP. To them, like to the rest of the Kenya population, one's salary has a high influence on how they work as opposed to the gratitude and appreciation one may get from the community. The study concluded that the appreciation of the police efforts in fighting crime by the community members is neutral to the implementation of $\mathrm{CP}$.

\section{Recommendations}

The research concludes that community factors have a major influence on the implementation of Community Policing in Nairobi County. It is therefore recommended that the government, through the Ministry of Interior and Coordination of National Government should address these factors through the following initiatives:

a. Sensitize the community on the importance of community policing as a strategy to combat crime within the community

b. Introduce police-community partnerships programs that will address the misconception and mistrust that exists between the two key stakeholders of community policing.

c. Organize regular dialogue sessions between the police and the community in order to promote positive relationships between the two stakeholders.

d. Adopt measures that address negative impacts of social, economic influences to effective implementation of community policing; to include cultural diversity and tribalism

d. Create avenues that facilitate public-private partnership efforts to support community-policing implementation in Nairobi County.

e. Provide facilities and equipments required to facilitate interactions between police and members of the community they serve for smooth implementation of CP.

f. Develop clear action plans to address negative aspects of cultural diversity and multi ethnicity among the population of Nairobi County since they reduce traction of community policing in the capital city.

\section{Conclusion}

Community policing plays a critical role in promoting police and community efforts in fighting crime. Existing literature confirms that community policing has tremendous potential, but its implementation in a metropolitan county like Nairobi has been elusive. The study recommends that community factors that impede implementation of this noble strategy needs to be addressed as a matter of urgency.

\section{References}

[1] Bittner, E. (2010). Aspects of police work. Boston: Northeastern University Press.

[2] Brand, M. W. \& Birzer, M. L. (2003). The benefits of community policing in rural Oklahoma. OH: Anderson Publishing. 
[3] Forman Jr, J. (2004). Community policing and youth as assets. Journal

[4] Considerations," Home Affairs Review, Volume XXXIV (No. 6): 114-23

[5] Gastrow, P. (2011). Termites at Work: Transnational Organized Crime and State Erosion in Kenya. New York: International Peace Institute.

[6] Giacomazzi, A., S. Riley and R. Merz. (2014). Internal and external challenges to implementing community policing: Examining comprehensive assessment reports from multiple sites. Criminal Justice Studies, 17(2), 223-238.

[7] Katz, D., and Kahn, R.L. (2011). The social psychology of organizations ( $2^{\text {nd }}$ Ed.). New York: John Wiley \& Sons.

[8] Kothari, C. R. (2014). Research Methodology: Methods and techniques. (2 ${ }^{\text {nd }}$ Ed).New Age International Publishers.

[9] Lee, J. (2010). Policing After 9/11: Community policing in an age of homeland security. Police Quarterly, 13(4), 347-366.

[10] Lilley, D.R. (2006).Assessingjurisdiction-levelcrimetrendsduringthe1990s: An analysis of the impact of policing changes. Dissertation Abstracts International, 67(05), 259. (UMINo.3216148).

[11] Manyange, Damaris N. (2014) The Paradigm Shift in Rethinking of National and Regional Security Strategy in East Africa, unpublished PhD Thesis

[12] Moore, M. (2012).Problem Solving, and Community Policing. Crime and Justice, 15, 99158.

[13] Mugenda, O. M. \& Mugenda, A. G. (2010). Research methods: Quantitative and qualitative Approaches. African Centre for Technology Studies, Nairobi

[14] Oliver, W. (2004). Community - oriented policing: A systematic approach to a policy framework for community policing. $3^{\text {rd }}$ edition.Upper Saddle River, NJ: Pearson.

[15] Reichel, P. L. (2002). Comparative criminal justice systems: A topical

[16] Roth, J. A., Roehl, J., \& Johnson, C. C. (2004). Trends in community policing. Community policing: Can it work, 3-29.

[17] Seagrave, T. (2011). Defining Community Policing. American Journal of Police, XV (2), 1-22.

[18] Thibault, E.A., Lynch, L.M. \& McBride, B.R. (2014). Proactive police management. $6^{\text {th }}$ edition. Upper Saddle River, NJ: Pearson.

[19] Toch, H. (2002). Stress in policing. American Psychological Association. 